\title{
Optimization of Intercropping Rice, Corn, and Soybeans in the Border Area of Sanggau Regency: a goal programming approach
}

\author{
Rusli Burhansyah ${ }^{*}$ and Sution \\ West Kalimantan Assessment Institute for Agricultural Technology, Budi Utomo No.45 Street \\ Siantan Hulu, Pontianak, Indonesia, Indonesia
}

\begin{abstract}
This study uses a goal programming approach for the dual purpose of planning the production of rice-corn-soybean intercropping in the Border Area of Sanggau Regency. In this study, seven objectives were formulated, (1) maximizing the income of rice-corn-soybean intercropping in a year, (2) minimizing farming costs, (3) minimizing labor, (4) maximizing urea fertilizer, (5) maximizing NPK fertilizer, (6) maximizing manure and (7) minimizing land area. The study was conducted in September-December 2019. The study used a survey method. The data collection method used purposive sampling. Respondents were farmers who plant intercropping rice-corn-soybean. The numbers of respondent was 30 people, data collection by random sampling. The method of data analysis was using income analysis, $\mathrm{R} / \mathrm{C}$, and Multi-Goal Programming. The results showed that optimization can be achieved with a yearly income goal of IDR 85,566,600; farm costs IDR 31,249,250, the labor of 6,024 people, use of urea fertilizer as much as $400 \mathrm{~kg}$, use of NPK fertilizer as much as $1,500 \mathrm{~kg}$, use of manure as much as $3,000 \mathrm{~kg}$, and land area 6,140 ha. Optimization is achieved when farmers cultivate intercropping ricecorn with an area of 1.99 ha and intercropping with soybean with an area of 0.95 ha.
\end{abstract}

\section{Introduction}

The threat of global food security is influenced by the increase in human population and the decrease in harvested area. Modernization of traditional systems with production-oriented and production-oriented planting practices and economics as a food security strategy for future generations [1]. Food self-sufficiency in rice, corn, soybeans for the Indonesian state must be achieved in the next few years. Commodities of rice, corn and soybeans as food and animal feed commodities. Corn commodity is needed by the animal feed industry. Soybean commodities are needed to meet the home industry of making tofu, tempeh, soy sauce, milk and so on. Fulfillment of food needs is still vulnerable, this condition occurs because it is still imported. Corn needs are met by $4 \%$ of imports, while the needs of soybeans are met by $80 \%$ of imports. The target of corn production is to increase to 23.16

\footnotetext{
* Corresponding author: burhansyahrusli@yahoo.com
} 
million tons (up about $18.10 \%$ from the previous year), soybean production to decrease by 0.89 million tons of soybeans or $-8.06 \%[2]$.

West Kalimantan's food production in 2019 includes; rice is around 847,875 tons, corn is about 238,745 tons (productivity $3.6 \mathrm{t} / \mathrm{ha}$ ), soybeans is around 530 tons (productivity is 0.58 tons/ha) [2]. Corn production in Sanggau Regency in 2019 reached 18,561 tons with a harvested area of 4,387 ha, productivity $4.23 \mathrm{t} / \mathrm{ha}$, higher productivity than the province of West Kalimantan (3.6 t/ha). Soybean production reaches 12 tons with a harvested area of $13 \mathrm{ha}$, so its productivity reaches 0.56 tons/ha. Corn and soybean commodity prices in the market tend to fluctuate depending on the harvest season. Although the prices of these two commodities fluctuate, demand for corn and soybeans is relatively high. Until now soybean is still a controversial commodity. Soybean agribusiness issues include; the selling price is relatively low so that the response of farmers to farming is less. The need for soybeanbased foods such as tofu and tempeh is increasing every year. This condition causes the demand for soybeans as a food raw material to increase. This encourages the government to continue to strive to meet the needs of corn and soybeans in the community[18].

National soybean and corn production cannot meet domestic demand, so they must be imported [6].This condition often triggers the fall in commodity prices of corn and soybeans. The government is trying to maintain the supply of soybeans to meet domestic production. One of the efforts to fulfill domestic corn and soybean production is through intensification and extensification. Corn and soybeans can be planted on dry land during the rainy season. The intercropping pattern of corn, rice, and soybeans is expected to meet domestic production.

Dry land is a potential and prospective land resource for agricultural land which reaches an area of about 20.15 million ha. The potential for extensification (area expansion) of food production reaches 13.26 million ha. However, the problem in dry land is that its productivity tends to be low and it is not used optimally. This condition depends on rainfall as a source of water supply. Water availability is an important factor in agricultural production. The availability of this water has contributed about $16 \%$ of the increase in production $[5,6,7,12]$.

The condition of land ecosystems in West Kalimantan Province consists of: wetlands covering an area of 3,659,736 ha (24.99\%), dry land with a slope of $<15 \%$ covering an area of 4,356,790 ha (29.74\%) and a slope of $>15 \%$ covering an area of 6,441. 956 ha (44.0\%). The use of land for agriculture is only about $13.85 \%$ of the total area. The West Kalimantan region belongs to a wet climate, the average annual rainfall varies from 2,663 to 4,191 mm, and agro-climatic zones A, B1, and C. This area has various parent materials consisting of alluvium, organic sedimentary matter, volcanic rocks. old, intrusive, sedimentary, and metamorphic rocks that make up the soil orders Histosols, Entisols, Inceptisols, Spodosols, Ultisols, and Oxisols. From the results of the analysis of the potential of land resources for the development of food commodities, it is directed at (a) land intensification for rice fields covering an area of 221,381 ha, secondary crops (corn, upland rice, legumes, tubers) covering an area of 173,581 ha, plantation crops. (rubber, oil palm, coconut, pepper, and coffee), including fruit trees covering an area of 570,266 ha, and for ponds covering an area of 7,394 ha, and (b) expansion of land for rice fields covering an area of 869,133 ha, fields for food crops 1,316,058 ha, plantations (oil palm, rubber, coconut, pepper, coffee) covering an area of 3,098,269 ha (priority on a $15-25 \%$ slope) and 1,300,374 ha (second priority on a slope of $25-40 \%$ ), and 25,437 ha for large ponds[10].

Application of technological innovation of soybean-corn intercropping system (turiman) in dry land is very prospective. Corn and soybean are prospective intercrops $[7,13]$. Several research results of the two crop intercropping system showed that the productivity of rice and legumes was higher than that of the monoculture system. Some of the advantages of intercropping rice and soybeans, among others, provide a complementary effect. 
Intercropping of cassava, upland rice, corn, soybeans, beans is very potential and prospective $[5,8]$. The upland rice-sweet corn intercropping system tends to have higher yields than other crop intercropping systems.

The research objectives to be achieved in this research are: (a) to determine the intercropping model of food crops, (b)To determine the target constraints that can be achieved, (c) To determine the sensitivity to the optimum solution that has been achieved.

\section{Research Method}

\subsection{Location, Time of Research, Data Processing and Sampling Methods}

In this study was using a survey method. The survey method is a systematic method for collecting information from a sample of the population to describe a larger population [19]. The study was conducted in villages in Sekayam District with the consideration that these villages already have a wider rice, corn and soybean cropping pattern than other villages. These villages include Pengadang Village, Kenaman Village, and Bungkang Village. The research period is from October to December 2019. The research is directed at farmers who grow rice, corn and soybeans based on information from the Field Agricultural Extension Officer, Sekayam District. The data collection method used interview with a structured questionnaire. Random sampling of respondents with the number of respondents is 30 people.

\subsection{Data Processing and Analysis Techniques}

Data collection is displayed in tabular form. Calculation of farmers' income from farming rice, corn, paddy, corn and soybeans using gross income analysis, net profit analysis with the following formula [19].

$$
\begin{gathered}
G M=G F I-T V C \\
N F I=G F I-T V C-T F C
\end{gathered}
$$

$$
\begin{aligned}
& \text { Where: } \\
& \text { GM }=\text { Gross margin } / \text { ha } \\
& \text { GFI }=\text { Gross farm income } / \text { ha } \\
& \text { TVC }=\text { Total variable cost } / \text { ha } \\
& \text { TFC }=\text { Total fixed cost } / \text { ha } \\
& \text { NFI }=\text { Net farm income } / \text { ha }
\end{aligned}
$$

Completing the optimization of rice, corn, soybeans using the QM program for window version 5 [16].

Purpose Function:

The function of the maximum (minimum) income from the intercropping pattern of rice, corn, and soybeans is mathematical. The general model of multi-purpose programming is as follows:

Minimum

$$
Z=\sum_{i=1}^{m}\left(d_{i}+d_{i}^{+}\right)
$$

Bond terms: 
For $\mathrm{i}=1,2, \ldots \mathrm{n}$

$$
\sum_{j=1}^{n} a_{i j X_{j}+d_{-i}-d+_{i}}
$$

For $\mathrm{K}=1,2, \ldots \cdot \mathrm{p}$

$$
\sum_{j=i}^{n} g_{k j X_{j}<o r>C}
$$

$$
\mathrm{J}=1,2, \ldots \mathrm{n}
$$

With assumption

$\mathrm{Xj}, \mathrm{d}+\mathrm{j}, \mathrm{d}-\mathrm{j} \geq 0$

$\mathrm{d}+\mathrm{j}, \mathrm{d}-\mathrm{j}=0$

Where:

di + , di-: the number of units of deviation that are deficient $(-)$ or excess $(+)$ relative to objective (b1);

Wi : the balance (ordinal or cardinal) against a unit deviation on the goal $\left(b_{1}\right)$

aij : relates to the objective of decision-making variables $(\mathrm{Xj})$

$\mathrm{Xj} \quad$ : the variable of decision making or activity that you want to find, for example production, selling, buying and credit activities

Bi : goals or targets to be achieved

Gkj : technology coefficient of ordinary constraint function;

$\mathrm{Ck} \quad$ : the amount of $\mathrm{k}$ resources available

$\mathrm{Z} \quad$ : the scalar value of the decision making criteria, that is objective function

\section{Result and Discussion}

\subsection{Geographical Location, Climate and Planting Pattern}

The geographic position of Sekayam sub-district is located at North Latitude (LU): 0 "49'10.05 and East Longitude (BT): 110" 25'31.65. (Fig.1). The area of Sekayam subdistrict is around $841.01 \mathrm{~km} 2$ or 84,101 ha. Rainfall in 2019 was recorded as much as 2,164 $\mathrm{mm}$, with an average of $180 \mathrm{~mm}$ per month and monthly rainy days 13 . Air temperature $22.3^{0}-34^{0} \mathrm{C}$, humidity $86.6 \%$, solar radiation $50-73 \%$. Most of the soil types found in Sekayam District are solid rock-red and yellow podsolic soil types [5].

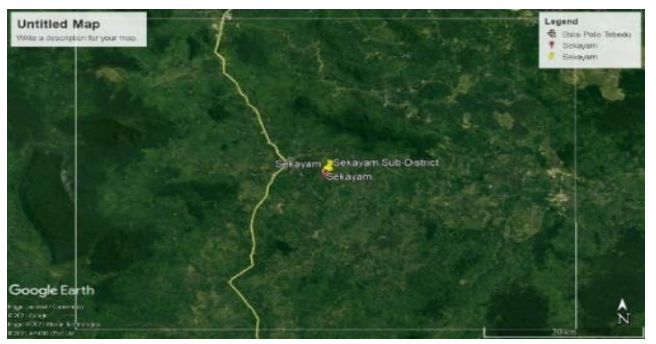

Fig. 1. Sekayam sub-district map

Based on the average rainfall data for 2011-2019 in Sanggau Regency. average per month about $250 \mathrm{~mm}$. The average number of rainy days is 14 days. The rainy season starts from September / October to February. The dry season starts from March/April to August (Figure 2). 


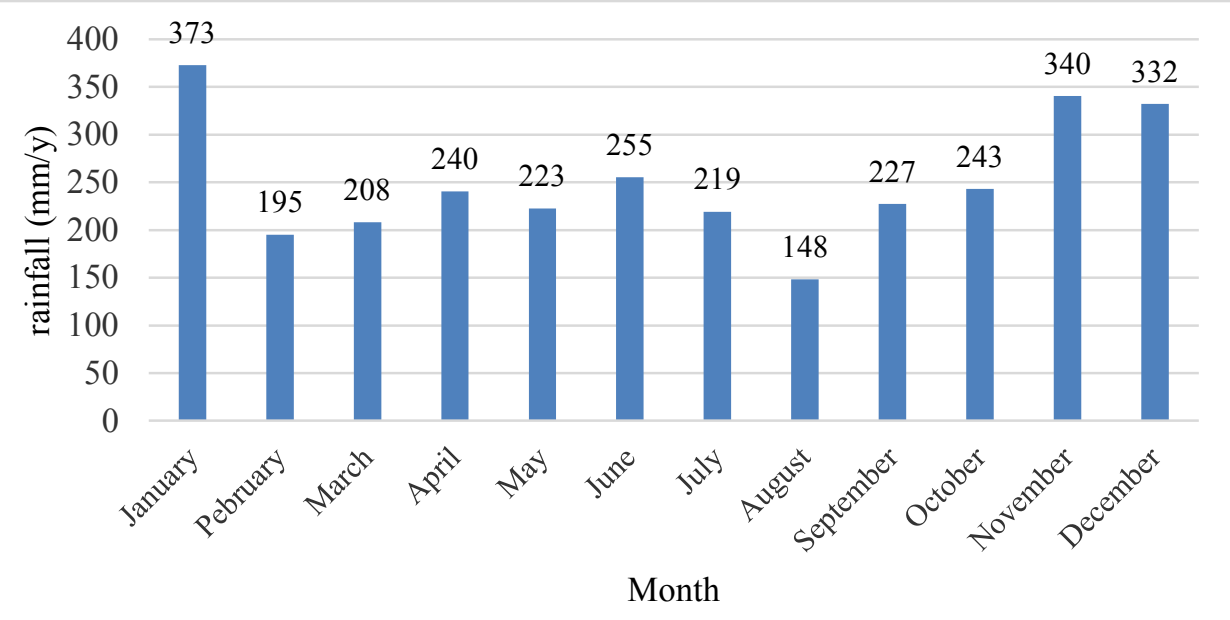

Fig.2. Annual rainfall in Sanggau district 2011-2019

Based on the results of the Focus Group Discussion at the farmer level, the cropping pattern was intercropping rice, corn, and soybeans. The following intercropping patterns were obtained (Figure 3). Rice-corn intercropping is planted in September, harvesting in December. Rice-soybean intercropping is planted in January harvest in April. The cornsoybean intercropping is planted from May to August.

Rice-Corn

Rice-Soybean

Corn-Soybean

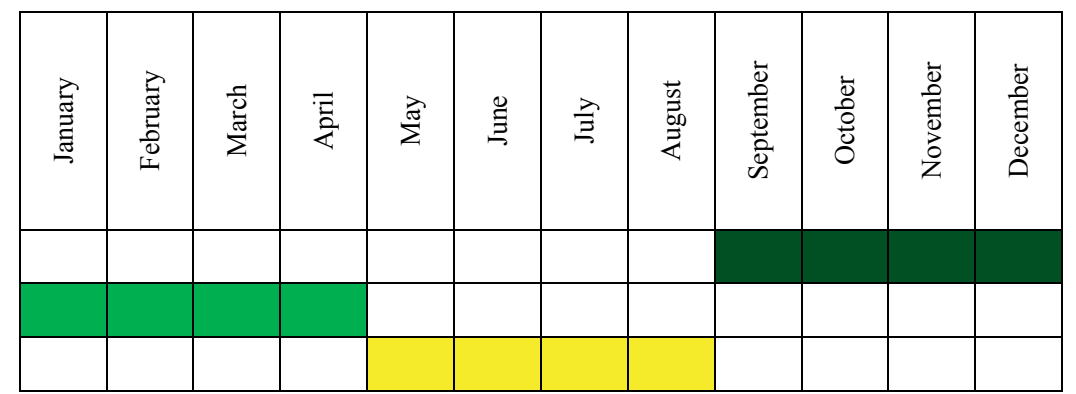

Fig. 3. The intercropping pattern of rice, corn, and soybean

The land potential in Sekayam District that can be planted with intercropping rice, corn and soybeans is around 6,140 hectares, consisting of 4,590 hectares of dryland and 1,550 hectares of land. From an area of 6,140 hectares, it is planned that around 1,131 hectares. Exiting food plant commodities include; field rice, corn, cassava, sweet potatoes, peanuts. Existing vegetable crop commodities include; large chilies, bird's eye chilies, eggplant, and long beans.

The productivity of intercropping rice-maize (X1) is 2.23 tons/ha of rice, 5.6 tons/ha of corn. The productivity of rice-soybean intercropping (X2) was 2.72 tons/ha, soybeans 1.39 tons/ha. The productivity of corn-soybean intercropping (X3) was 4.48 tons/ha, soybeans 1.14 tons/ha. Research on corn-soybean intercropping by [18]. As a result, maize productivity of the Nasa-29 variety was around 9.34 tons/ha, and the productivity of Anjasmoro, Dena, and Devon soybean varieties reached 1.9 tons/ha in rainfed rice fields in Central Lampung, Lampung Province. The results of the intercropping research conducted by [19] stated that rice productivity reached 2.17 tons/ha and corn productivity reached 3.95 tons/ha. The result of his research stated that average productivity of corn reached 14.1 tons/ha and soybean productivity reached 2.37 tons/ha. 
The results of the analysis of farmers' income per hectare based on the intercropping model of rice, corn and soybeans carried out by farmer's are presented in Table 1 below. From the analysis of gross income from 3 intercropping models of rice, corn and soybean, it can be seen that the intercropping model of corn rice is the largest income with a total income of IDR 33,699,000, a profit of IDR 22,504,000 with an $\mathrm{R} / \mathrm{C}$ ratio of 3.04. The overlapping cropping pattern of upland rice and maize was also investigated by Hipi et al. (2020). The research was conducted on dry land in Gorontalo Province. The average productivity of rice is around $2.17 \mathrm{t} / \mathrm{ha}$, while maize productivity can reach $3.61 \mathrm{t} / \mathrm{ha}$.

Table 1. Costs and Income of the Intercropping Model of Rice, Corn and Soybean in Sekayam, 2019

\begin{tabular}{|c|c|c|c|c|c|c|}
\hline \multirow{2}{*}{ Description } & \multicolumn{2}{|c|}{ Rice-Corn (X1) } & \multicolumn{2}{|c|}{ Rice-Soybean (X2) } & \multicolumn{2}{|c|}{ Corn-Soybeans (X3) } \\
\hline & Input & Output & Input & Output & Input & Output \\
\hline Material Cost & $5,895,500$ & & $3,711,250$ & & $5,542,500$ & \\
\hline \begin{tabular}{|l|} 
Labour \\
wages
\end{tabular} & $5,180,000$ & & $5,260,000$ & & $5,660,000$ & \\
\hline Total cost & $11,075,500$ & & $8,971,250$ & & $11,202,500$ & \\
\hline $\begin{array}{l}\text { Rice } \\
\text { production }\end{array}$ & 2,239 & & 2,727 & & & \\
\hline Price & 5,000 & $11,195,000$ & 5,000 & $13,635,000$ & & \\
\hline $\begin{array}{l}\text { Soybean } \\
\text { production }\end{array}$ & & & 1,397 & & 1,140 & \\
\hline Price & & & 8,000 & $11,176,000$ & 8,000 & $9,120,000$ \\
\hline $\begin{array}{l}\text { Corn } \\
\text { production }\end{array}$ & 5,626 & & & & 4,484 & \\
\hline Price & 4,000 & $22,504,000$ & & & 4,000 & $17,936,000$ \\
\hline \begin{tabular}{|l|} 
Total \\
Revenue
\end{tabular} & & $33,699,000$ & & $24,811,000$ & & $27,056,000$ \\
\hline Profit & & $22,504,000$ & & $13,635,000$ & & $15,853,500$ \\
\hline R/C Ratio & & 3.04 & & 2.77 & & 2.42 \\
\hline
\end{tabular}

Soy-corn intercropping technology can increase farmers' income in the Tambang Emas Village, Pamengan Selata, Merangi Regency, Jambi Province from 2018-2019. Soy-corn intercropping farmers' income is IDR. 18,000,000-IDR21,000,000 per season or higher, around IDR. 5,450,000-IDR11,700,000 per season for monocultures of rice or soybeans. The $\mathrm{R} / \mathrm{C}$ of the intercropping pattern was 1.72-2.04 compared to the monoculture pattern of 1.13-20 [20] The rice-corn intercropping pattern increased rice production to 5.19-5.85 tons ha- 1 and corn reached 5.43-6.28 tons ha-1, with a $\mathrm{B} / \mathrm{C}$ ratio of 2.68 , an $\mathrm{R} / \mathrm{C}$ ratio of 3.12 compared to monoculture pattern of rice or corn with $\mathrm{B} / \mathrm{C}$ ratio 1.24 and 1.88 [22].

Income, production costs, availability of labor, availability of fertilizers, and land area are important aspects of farming planning. Problems of income, productivity, production costs will be attempted if farmers are faced with limited resources, both land area, capital for production facilities and paying labor wages. The implication is, although an intercropping model can provide the highest income, it is not necessarily the best choice to implement because of the area, productivity, and farming costs. How to determine the objectives of more than one activity, so that the intercropping farming model is optimal (can maximize income). The results of the analysis applying multi object (goal) programming which can be presented below can solve this problem. 
Table 2. Priority Function Objectives

\begin{tabular}{|c|c|l|}
\hline No & Factor & \multicolumn{1}{c|}{ Description } \\
\hline 1 & P1 & Maximizing intercropping farm income in a year IDR 85,566,000 \\
\hline 2 & P2 & $\begin{array}{l}\text { Minimizing the cost of intercropping farming in a year not more than } \\
\text { IDR 31,249,250 }\end{array}$ \\
\hline 3 & P3 & Minimize the number of workers not to exceed 6,024 people \\
\hline 4 & P4 & Maximizing the amount of urea fertilizer used is $4,00 \mathrm{~kg}$ \\
\hline 5 & P5 & Maximizing the amount of NPK fertilizer used is $1,500 \mathrm{~kg}$ \\
\hline 6 & P6 & The maximum amount of manure used is 3,000 kg \\
\hline 7 & P7 & Minimizing the land used by 6,140 ha \\
\hline
\end{tabular}

Destination function: Minimization

$Z=P_{1}\left(d_{1}^{-}+d_{1}^{+}\right)+P_{2}\left(d_{2}^{-}+d_{2}^{+}\right)+P_{3}\left(d_{3}^{-}\right)+P_{4}\left(d_{4}^{-}+d_{4}^{+}\right)+P_{5}\left(d_{5}^{-}+d_{5}^{+}\right)+P_{6}\left(d_{6}^{-}+d_{6}^{+}\right)+P_{7}\left(d_{7}^{-}\right)$

Constrain:

$$
\begin{aligned}
& 3699000 X_{1}+24811000 X_{2}+27056000 X_{3}+d_{1}-d_{1}^{+}=85566000 \\
& 11075999 X_{1}+11075000 X_{2}+112025000 X_{3}+d_{2}-d_{2}=31249250 \\
& 64 X_{1}+65 X_{2}+67 X_{3}+d_{3}=6.024 \\
& 150 X_{1}+100 X_{2}+150 X_{3}+d_{4}-d_{4}^{+}=400 \\
& 600 X_{1}+400 X_{2}+500 X_{3}+d_{5}^{-} d_{5}^{+}=1.500 \\
& 1500 X_{1}+1500 X_{3}+d_{6}-d_{6}^{+}=3.000 \\
& X_{1}+X_{2}+X_{3}+d_{7}=6.140 \\
& d_{1}^{+}+d_{2}^{+}+d_{4}^{+}+d_{5}^{+}+d_{6}^{+}+d_{7}^{+}+d_{1}+d_{2}+d_{3}+d_{4}+d_{5}+d_{6}+ \\
& \quad d_{7}+X_{1}
\end{aligned}
$$

From the results of the multi-objective analysis (Goal) Programming, the deviation variable values were obtained (Table 3 ). That the value of the deviation for the first target constraint to maximize the income of intercropping farming in a year is IDR $85,566,000$. The second target of intercropping farming budget in a year is not more than IDR $31,249,250$. The fifth target is the amount of NPK fertilizer used is $1,500 \mathrm{~kg}$. The sixth amount of manure used is $3,000 \mathrm{~kg}$ and the seventh target area of land used not to exceed 6,140 ha is zero. This means the goals (goals) for the first, second, fifth, sixth, and seventh goal constraints. Meanwhile, the deviation value under the third, fourth, fifth and seventh constraints is not zero, meaning that the goal is not achieved. The variable value for upland rice-corn intercropping $(\mathrm{X} 1)=1.9$ ha upland rice-soybean intercropping $(\mathrm{X} 2)=0.73$ ha and corn-soybean intercropping $(\mathrm{X} 3)=0.0950$ ha farmers are advised to plant intercropping. upland rice-corn and corn-soybean intercropping. 
Tabel 3. Output Model Multi-Objective (Goal) Programming

\begin{tabular}{|l|r|l|}
\hline \multicolumn{1}{|c|}{ Decision Variable } & \multicolumn{2}{|c|}{ Z } \\
\cline { 1 - 1 } $\mathrm{X} 1=1.990$ & \multicolumn{2}{|c|}{12.019} \\
\cline { 1 - 2 } X2 $=0.73$ & \multicolumn{2}{|c|}{} \\
\cline { 1 - 2 } X3 $=0.0950$ & 0.000 & Reached \\
\cline { 1 - 2 } Variable Deviational & \multicolumn{1}{|c|}{ Target } & Information \\
\hline DA1 & 0.000 & \\
\hline DB1 & 0.000 & Reached \\
\hline DA2 & 0.000 & \\
\hline DB2 & $5,848.209$ & Reached \\
\hline DB3 & 26.520 & Reached \\
\hline DB4 & 0.000 & \\
\hline DA5 & $13,507.030$ & Reached \\
\hline DB5 & 0.000 & \\
\hline DA6 & 0.000 & Reached \\
\hline DB6 & 0.000 & \\
\hline DA7 & $6,137.265$ & Reached \\
\hline DB7 & & \\
\hline
\end{tabular}

\subsection{Sensitivity Analysis}

Sensitivity analysis is used to identify sensitive variables, so special attention can be taken in estimating and selecting solutions with almost all of the good values. The sensitivity range of agricultural resources that is subject to this binding state is shown in the right hand side ranges (Table 4), which explains the sensitivity. the value of the optimal program for changes in resource availability or the value to the right. From the results of the sensitivity analysis in completing the right hands side ranges, there are 2 LINGO outputs showing that the target of maximizing rice, corn and soybean intercropping revenues of IDR. 85,560,000 per year can still be increased by IDR. 436,892, - and can be reduced to infinity. The target cost of farming can be increased by IDR 102,926,700 and reduced to infinity. The workforce target can be increased to infinity and reduced to 5,848 people. The target of using urea fertilizer can be increased to infinity and reduced by $26.519 \mathrm{~kg}$. The target of using NPK fertilizer can be increased to infinity and reduced to $7,030 \mathrm{~kg}$. The target of using manure can be increased to $185.1071 \mathrm{~kg}$ and reduced to 373,4585 . Meanwhile, target land area can be increased to infinity and reduced to $6,137.26 \mathrm{~kg}$.

Table 4. Value of Agricultural Resource Sensitivity Range in Right Hand Side Ranges

\begin{tabular}{|l|c|r|r|r|}
\hline \multicolumn{2}{|c|}{ Activities } & $\begin{array}{c}\text { Current } \\
\text { Values }\end{array}$ & \multicolumn{1}{c|}{$\begin{array}{c}\text { Allowable } \\
\text { Increase }\end{array}$} & $\begin{array}{c}\text { Allowable } \\
\text { Decrease }\end{array}$ \\
\hline & Simbol & & & \\
\hline Revenue & $\mathrm{P}_{1}$ & $85,560,000$ & $436,892,4$ & Infinity \\
\hline Farming Cost & $\mathrm{P}_{2}$ & $31,249,350$ & $102,926,700$ & Infinity \\
\hline Labour & $\mathrm{P}_{3}$ & 6.024 & Infinity & $5.848,209$ \\
\hline Urea Fertilizser & $\mathrm{P}_{4}$ & 400 & Infinity & 26,519 \\
\hline NPK Fertiizier & $\mathrm{P}_{5}$ & 1.500 & Infinity & 7,030 \\
\hline Manure fertilizier & $\mathrm{P}_{6}$ & 3.000 & 185,071 & 373,4585 \\
\hline Land area & $\mathrm{P}_{7}$ & 6.140 & Infinity & $6.137,265$ \\
\hline
\end{tabular}


The intercropping farming of rice-corn, rice-soybean, corn-soybean can be successful if farmers fully implement the technology package recommendation. Crop intercropping technology can increase production optimize land, save production costs, increase farmer; $\mathrm{s}$ incoe. The factors that influence the application of intercropping are age, experience and farmer's perception [22].

The application of intercropping rice-corn $\left(\mathrm{X}_{1}\right)$, planting rice-soybean $\left(\mathrm{X}_{2}\right)$, cornsoybean $\left(\mathrm{X}_{3}\right)$ at the farmer level is successful if farmers adopt intercropping based on the recommended technology package, planting time. The response of farmers to the cornsoybean intercropping technology is very good. Farmer's responses to the technology componet of soybean intercopping include; processing $(69.57 \%)$, seed treatment $(78.26 \%)$, spacing $(95.65 \%)$, ease of planting corn $(95.65 \%)$, case of harvesting turiman-jale $(69.57 \%)$ and the ability to increase IP $(65.22 \%)$ [23].

\section{Conclusion}

The results showed that (1) the income of rice-corn intercropping farming was IDR $33,699,000, \mathrm{RC}=3.4$, rice-soybean intercropping farm income is IDR $24,811,000, \mathrm{R} / \mathrm{C}=$ 2.77. The income of corn-soybean intercropping farming is IDR $27,056,000, \mathrm{R} / \mathrm{C}=2.42$. (2) The maximum income of food crop intercropping is IDR 85,566,600 at a cost of IDR $31,249,250$ with an area of 1 rice-corn intercropping 1.99 ha and rice-soybean intercropping covering an area of 0.73 ha. Food crop intercropping income optimization is achieved with the availability of a workforce of $6,024 \mathrm{HOK}$, the availability of urea fertilizer as much as $400 \mathrm{~kg}$, the availability of NPK fertilizer as much as $1,500 \mathrm{~kg}$, the availability of manure as much as $3,000 \mathrm{~kg}$ and the availability of land 6,140 ha. Based on the sensitivity analysis, it can be seen that all of the target constraints can fulfill the objective function.

Optimizing farmers' income is achieved by planting rice-maize intercropping model covering an area of 1.90 ha and rice-soybean 0.73 ha. The planting time of rice-corn intercropping is September-December. The planting time of rice-soybean intercropping is January-April.

\section{References}

1. A. Ahmad, M. A. Wahid, M.W. Fazal, M.U.Anees, M.A. Arshad and M.T Saeed. American-Eurasian J. Agric. \& Environ. Sci., 1611 (2016)

2. Statistical Bureau, Statistic Yearbook of Indonesia (2020)

3. Ministry of Agriculture.Agricultural land statistics 2009-2013. (2014)

4. Statistical Bureau, West Kalimantan in Figure (2020)

5. Statistical Bureau, Sanggau Regency in Figure (2020)

6. Slameto, Medidaliyantisyah, W.Wibawa. ICOP Conf.Series: Earth Environmental Science 807 (2021)

7. E. Susilo. Thesis (unpublished) Bogor Agricultural Institute. (2004)

8. S Suzanna and S.R.E Hutapea. Irigation in Indonesia the role of society and research.LP3ES, (1995)

9. Haryono. Impact of irrigation network development on production, distribution and income. Indonesian Agency for Agricultural Research and Development (2010)

10. T.B. Purwantini, R.S.S Rivai, E.Suryani. Proceeding: Farmers and Agricultural Development (Center for Socio Economic and Agricultural Policy). (2012)

11. N.A.Fuadi, Thesis (unpublished) Bogor Agricultural Institute. (2016) 
12. Hikmatullah, N. Suharta, and A. Hidayat. J Sumberdaya Lahan.2,1 (2008)

13. East Java AIAT. Indonesian Agency for Agricultural Research and Development.(2018)

14. Musyafak, Sution, A.Subekti, S.Nurita, S.S. Wibowo. D.Fardenan. Indonesian Agency for Agricultural Research and Develompent..(2018)

15. E. Susilo and Parwito. J.Agroqua 11,2 (2013)

16. H.Pujiwati. Thesis (unpublished) Bogor Agricultural Institute, (2004)

17. H.Gebru. J.Biology, Agriculture and Healthcare.5,7 (2015)

18. C.Sevilla, J.A.Ochave, T.G.Punsalan, B.P.Regala, G.G.Uriarte. Pengantar Metode Penelitian (UI Press, 1993)

19. N.Mamun, Departemen of Agricultural Economic University of Nigeria, Nsukka. (2013)

20. Adri, Jumakir, Rustam. Proceeding $3^{\text {rd }}$ International Conference on Security in Food, Renewable Resources, and Natural Medicines (SFRN 2019) (2019)

21. C.O.I. Hastuti, R.Purnamayani, H.Hermawan and H.Syahbuddin. IOCP Conf.Series:Earth and Environmental Science 807 (2021)

22. E.Nurwahyuni, F.D. Arianti and Y.Hindarwati. ICOP Conf.Series: Earth Environmental Science $\mathbf{8 0 7}$ (2021) 